
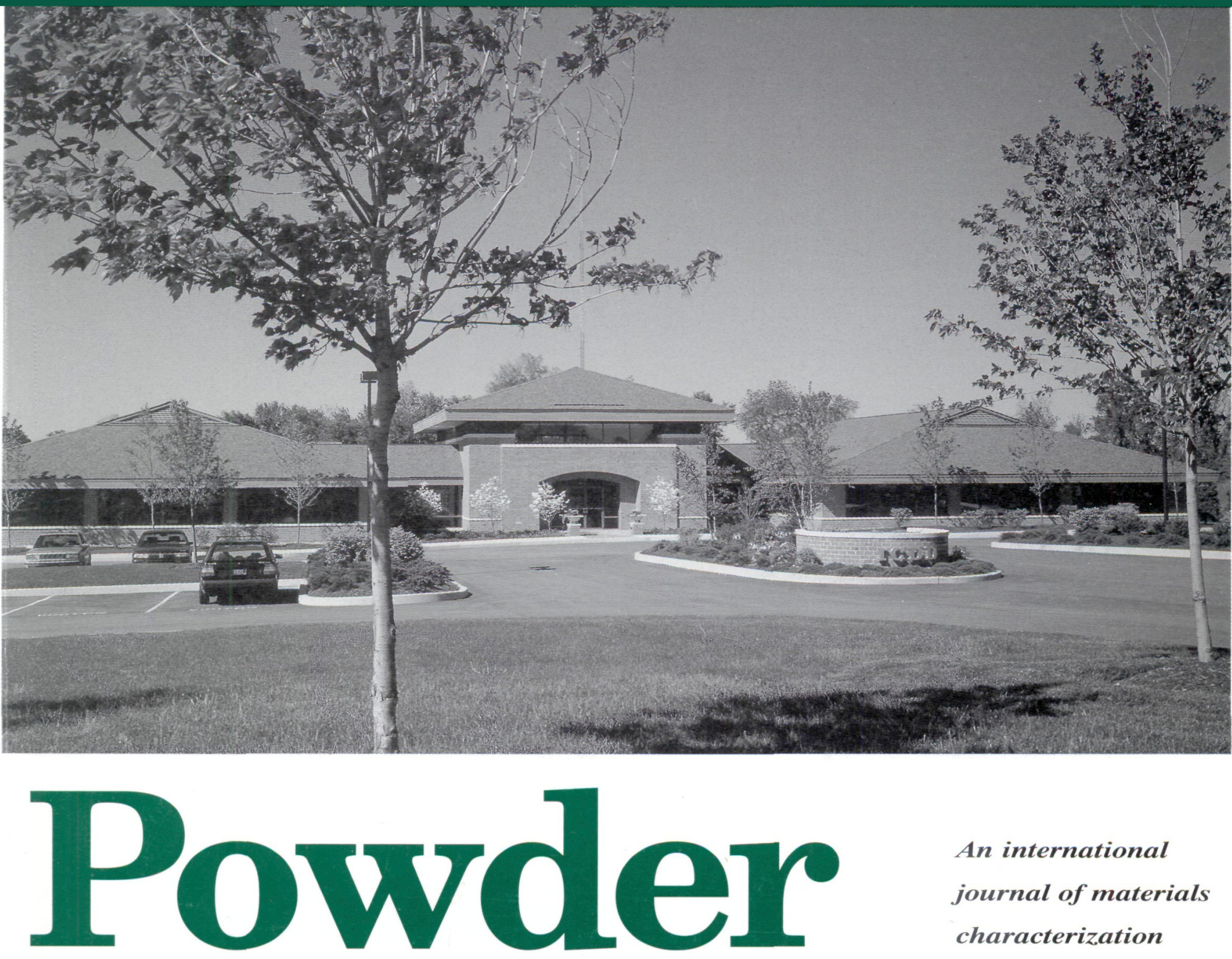

An international

journal of materials

characterization

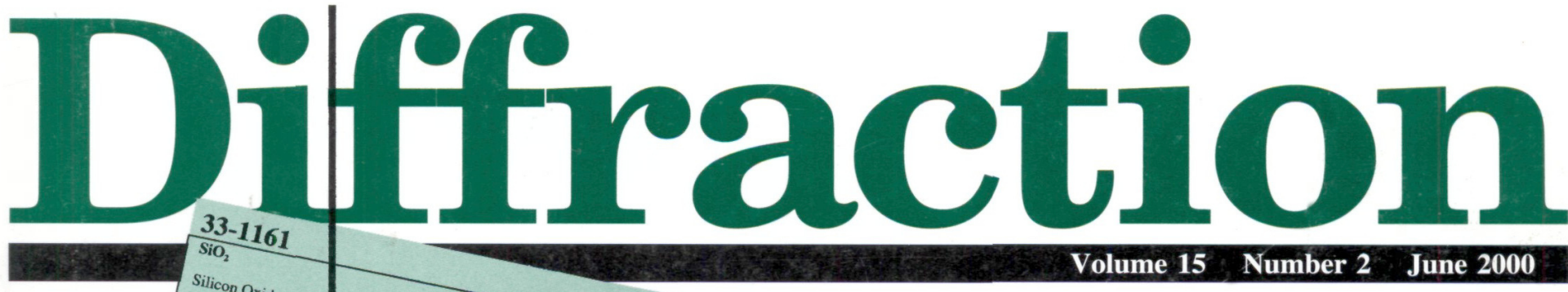

Volume 15 Number 2 June 2000

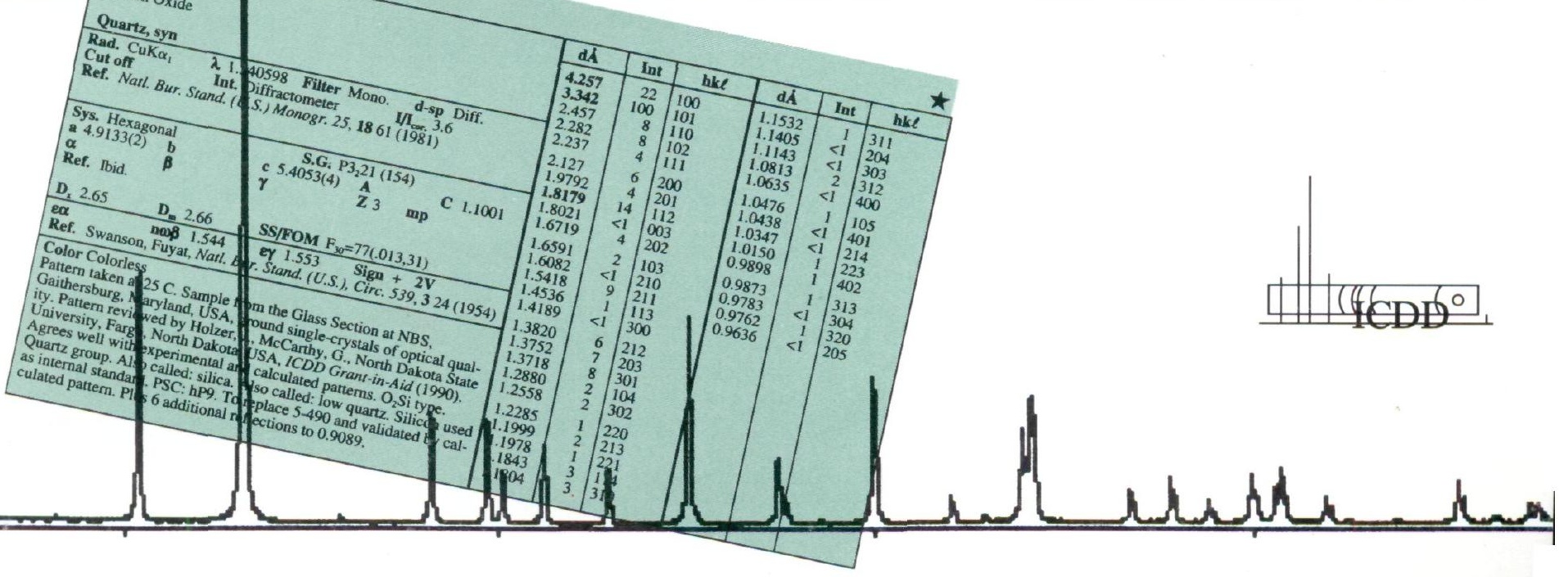




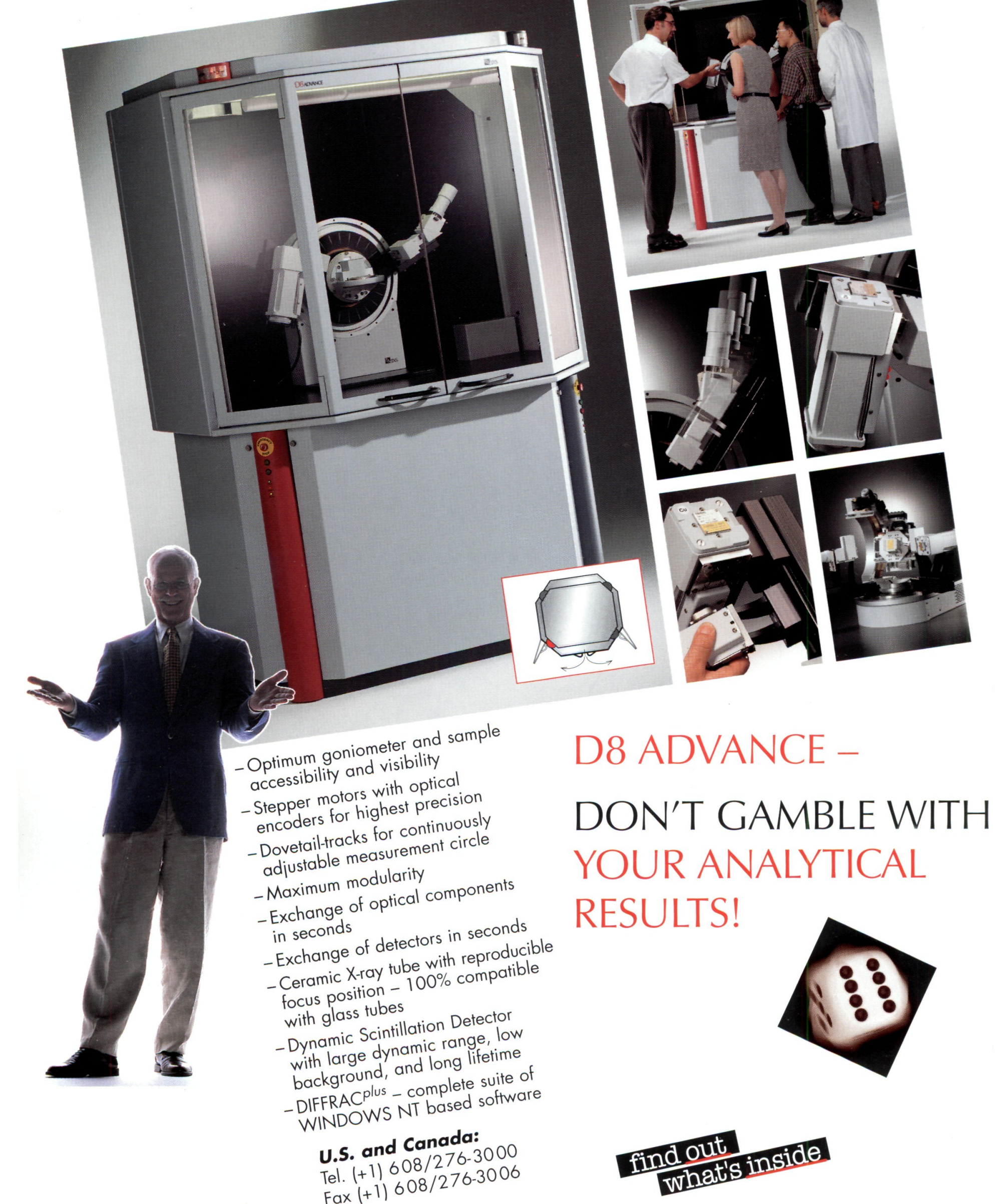
Germany: Tel. (+49) 721/595- 28887 Fax $(+49) 721 / 595$

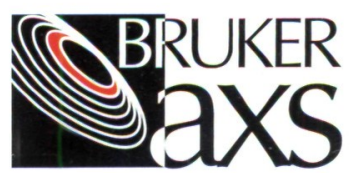

BRUKER ADVANCED X-RAY SOLUTIONS 


\section{X-ray diffraction}

for today

\section{and tomorrow}

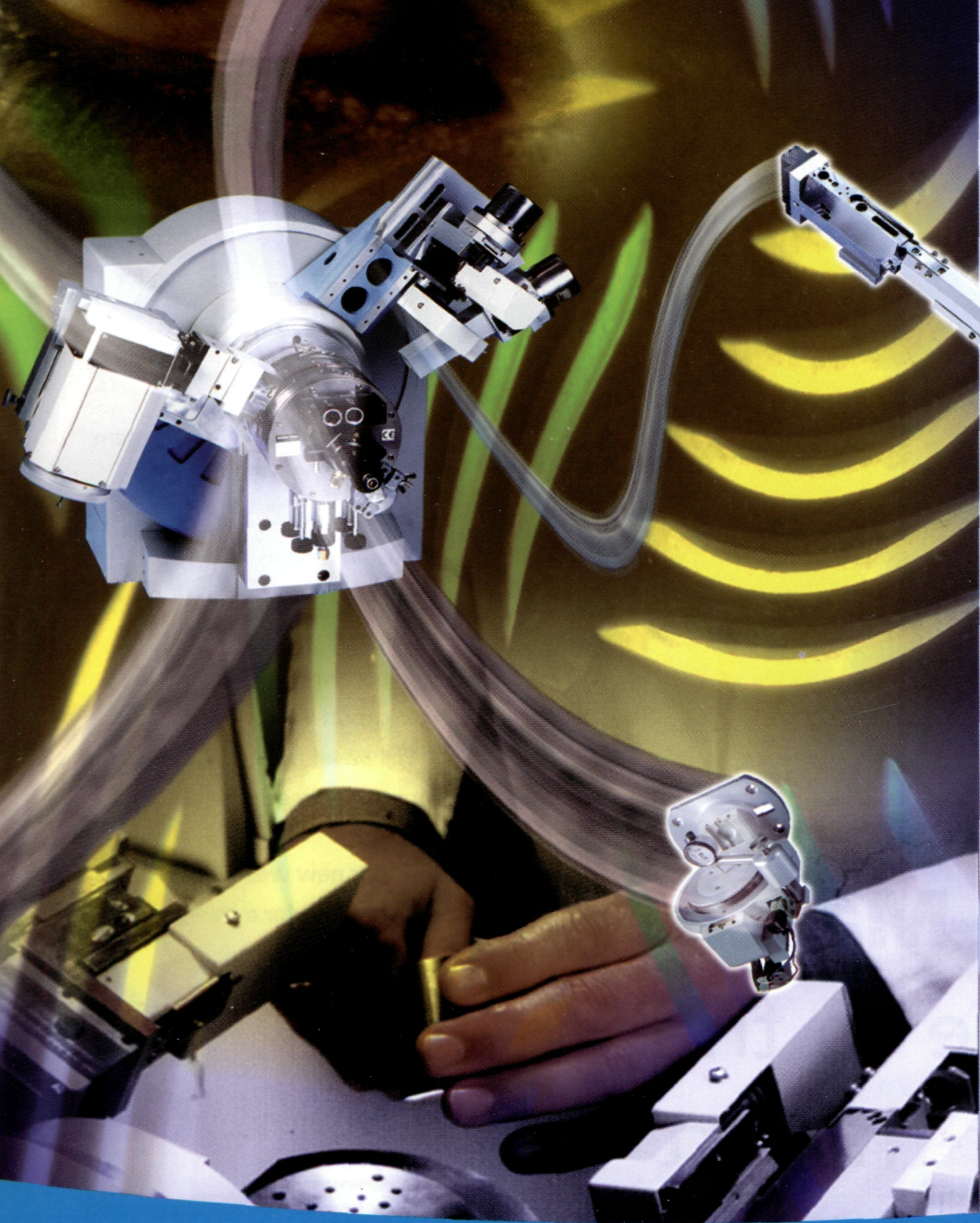

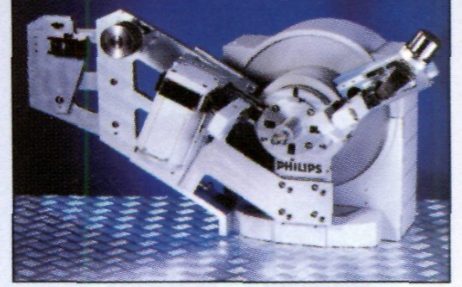

The inevitability of change has long been recognized and the pace of change is accelerating at an ever increasing rate. This is true in the laboratory domain as in every other aspect of modern life. What you require from your X-ray diffractometer could be a world apart from your expectations today.

The Philips X'Pert PRO diffractometer system is an $\mathrm{X}$-ray diffraction system with a virtually limitless capacity to adapt to changing circumstances. the PreFIX (Pre-aligned, Fast-Interchangeable XRay optics) system enables instruments to be reconfigured in a few minutes to handle different types of analysis.

A totally open design architecture guarantees full freedom to accommodate further advances in years to come.

For more information: Philips Analytical Lelyweg 1,7602 EA, Almelo, The Netherlands Tel. : +31 (546) 534444 Fax : +31(546) 534592

www.analytical.philips.com 
An International Journal of Materials Characterization

Editor-in-Chief

Ting C. Huang

6584 Radko Drive

San Jose, CA 95119-1924 U.S.A.

huang@icdd.com

\section{Managing Editor}

Shannon Mattaboni

JCPDS-International Centre for Diffraction Data

12 Campus Blvd.

Newtown Square, PA 19073-3273 U.S.A.

mattaboni@lcdd.com

Editor for Reviews and Reprints

Deane K. Smith

1652 Princeton Drive

State College, PA 16803-3273 U.S.A.

smithdeane@aol.com

Editor for New Diffraction Data

William E. Mayo

Rutgers University

Ceramics Department

Piscataway, NJ 08855-0909 U.S.A.

edisonjam@ aol.com

Western European Editor

Norberto Masciocchi

Università di Milano

Dipartimento di Chimica

Strutturale e Stereochimica Inorganica

Via Venezian, 21

20133 Milano, Italy

norbert@csmtbo.mi.cnr.it

Eastern European Editor

Jaroslav Fiala

SKODA Research Ltd

31600 Plzeñ, Czech Republic

jaroslav.fiala@vsb.cz

Editor for Southeast Asia

Brian H. O'Connor

Curtin University

GPO Box U 1987, Perth 6001

Western Australia, Australia

toconnorb@cc.curtin.edu.au

\section{Editor for Japan}

Hideo Toraya

Ceramics Research Lab

Nagoya Institute of Technology

Asahigaoka, Tajimi 507 Japan

toraya@crl.nitech.ac.jp

International Reports Editor

Winnie Wong- $\mathrm{Ng}$

National Institute of Standards and Technology

100 Bureau Drive Stop 8520

Gaithersburg, MD 20899-8520 U.S.A.

winnie.wong-ng@ nist.gov

Editorial Advisory Board

P. Bayliss, Sydney, Australia

C. Z. Bojarski, Katowice, Poland

A. Brown, Dorset, England

D. Cox, Upton, New York

L. Frevel, Midland, Michigan

P. Gado, Budapest, Hungary

H. Goebel, Munchen, Germany

R. Jenkins, Newtown Square, Pennsylvania

G. G. Johnson Jr., State College, Pennsylvania

Q. Johnson, Livermore, California

J. I. Langford, Birmingham, U.K.

D. Louër, Rennes, France

G. J. McCarthy, Fargo, North Dakota

H. F. McMurdie, Gaithersburg, Maryland

M. E. Mrose, Gaithersburg, Maryland

M. Nichols, Livermore, California

R. L. Snyder, Columbus, Ohio

T. Yamanaka, Tokyo, Japan

R. A. Young, Atlanta, Georgia

AlP Production: Lin Miller, Editorial Supervisor

Andrea Witt, Journal Coordinator

Kelly Quigley, Chief Production Editor
Powder Diffraction is a quarterly journal published by the JCPDS-International Centre for Diffraction Data through the American Institute of Physics (AIP). Powder Diffraction is a journal of practical technique, publishing articles relating to the widest range of application-from mineral analysis to epitactic growth of thin films and to the latest advances in software. Although practice will be emphasized, theory will not be neglected especially as its discussion will relate to better understanding of technique.

Submit manuscripts ( 3 copies) to the most appropriate Powder Diffraction Editor listed on this page. The Editors will consider all manuscripts received, but assume no responsibility regarding them. Materials will be returned only when accompanied by appropriate postage. There is no publication charge. See Powder Diffraction Notes for Authors for additional information.

Proofs and all correspondence concerning papers in the process of publication should be addressed to: Editorial Supervisor, Powder Diffraction, AIP, Suite 1NO1, 2 Huntington Quadrangle, Melville, NY 11747-4502.

For advertising rates and schedules contact AIP Advertising Department. Orders, advertising copy, and offset negatives should be sent to: Advertising Department, American Institute of Physics, Suite 1NO1, 2 Huntington Quadrangle, Melville, NY 11747-4502; phone: (516) 576-2440; fax: (516) 576-2481.

\begin{tabular}{|c|c|c|c|c|}
\hline $\begin{array}{l}\text { Subscription } \\
(2000)\end{array}$ & U.S.A \& Canada & $\begin{array}{l}\text { Mexico, Central } \\
\text { \& South America }\end{array}$ & $\begin{array}{l}\text { Europe, Mid-East } \\
\qquad \& \text { Africa* }\end{array}$ & $\begin{array}{l}\text { Asia \& } \\
\text { Oceania* }\end{array}$ \\
\hline $\begin{array}{l}\text { Individual } \\
\text { Institutional } \\
\text { or Library }\end{array}$ & $\begin{array}{r}\$ 60 \\
\$ 105\end{array}$ & $\begin{array}{r}\$ 85 \\
\$ 105\end{array}$ & $\begin{array}{r}\$ 85 \\
\$ 105\end{array}$ & $\begin{array}{r}\$ 85 \\
\$ 105\end{array}$ \\
\hline
\end{tabular}

"Subscription rates to Eastern Hemisphere include air freight service.

Back-Number Prices. 2000 single copies: $\$ 30$. Prior to 2000 single copies: $\$ 30$.

Subscription, renewals, and address changes should be addressed to AIP Circulation and Fulfillment Division (CFD), Suite 1NO1, 2 Huntington Quadrangle, Melville, NY 11747-4502. Allow at least six weeks advance notice. For address changes please send both old and new addresses and, if possible, include a mailing label from the wrapper of a recent issue.

Claims, Single Copy Replacement and Back Volumes: Missing issue requests will be honored only if received within six months of publication date (nine months for Australia and Asia). Single copies of a journal may be ordered and back volumes are available in print or microform. Individual subscribers please contact AIP Circulation and Fulfillment Division (CFD) at (516) 576-2288; (800) 344-6901. Institutional or library subscribers please contact AIP Subscriber Services at (516) 576-2270; (800) 344-6902.

Reprint Billing: Contact: AIP Circulation and Fulfillment Division, Melville, NY 11747 4502; (516) 576-2230; (800) 344-6909.

Copying: Single copies of individual articles may be made for private use or research Authorization is given (as indicated by the Item Fee Code for this publication) to copy articles beyond the use permitted by Sections 107 and 108 of the U.S. Copyright Law, provided the copying fee of $\$ 6$ per copy per article is paid to the Copyright Clearance Center, 222 Rosewood Drive, Danvers, MA 01923, USA. Persons desiring to photocopy materials for classroom use should contact the CCC Academic Permissions Service. The Item Fee Code for this publication is $0885-7156 / 2000 \$ 6.00$.

Authorization does not extend to systematic or multiple reproduction, to copying for promotional purposes, to electronic storage or distribution, or to republication in any form. In all such cases, specific written permission from AIP must be obtained.

Permission for Other Use: Permission is granted to quote from the journal with the customary acknowledgment of the source. To reprint a figure, table, or other excerpt requires the consent of one of the authors and notification to AIP.

Requests for Permission: Address requests to AIP Office of Rights and Permissions, Suite 1NO1, 2 Huntington Quadrangle, Melville, NY 11747-4502; Fax: 516-576-2450 Telephone: 516-576-2268; E-mail: rights@aip.org.

Document Delivery: Copies of journal articles can be ordered for online delivery from the Buy An Article online document delivery service (http://ojps.aip.org/jhtml/artinphys/). Reprints: Reprints can be ordered with or without covers only in multiples of 50 (with a minimum of 100 in each category) from AIP, Circulation \& Fulfillment/Reprints, Suite 1NO1, 2 Huntington Quadrangle, Melville, NY 11747-4502; Fax: 516-349-9704; Telephone: 800-344-6909 (in U.S. and Canada), or 516-576-2234.

Powder Diffraction (ISSN: 0885-7156) is published quarterly (4X annually) by the JCPDS-International Centre for Diffraction Data through the American Institute of Physics. 1999 Subscription rates: US\$105. POSTMASTER: Send address changes to Powder Diffraction, AIP Circulation \& Fulfillment Division, Suite 1NO1, 2 Huntington Quadrangle, Melville, NY 11747-4502. Periodicals postage paid at Huntington Station, NY 11746, and additional mailing offices.

Online Availabllity: Abstracts of journal articles published by the AIP and Member Societies (and several other physics publishers) are available from AIP's SPIN database, via AIP's Online Journal Publishing Service (OJPS) (http://ojps.aip.org).

Copyright 2000 JCPDS-International Centre for Diffraction Data, 12 Campus Blvd., Newtown Square, PA 19073-3273. All rlghts reserved. www.icdd.com/products/journals.htm 

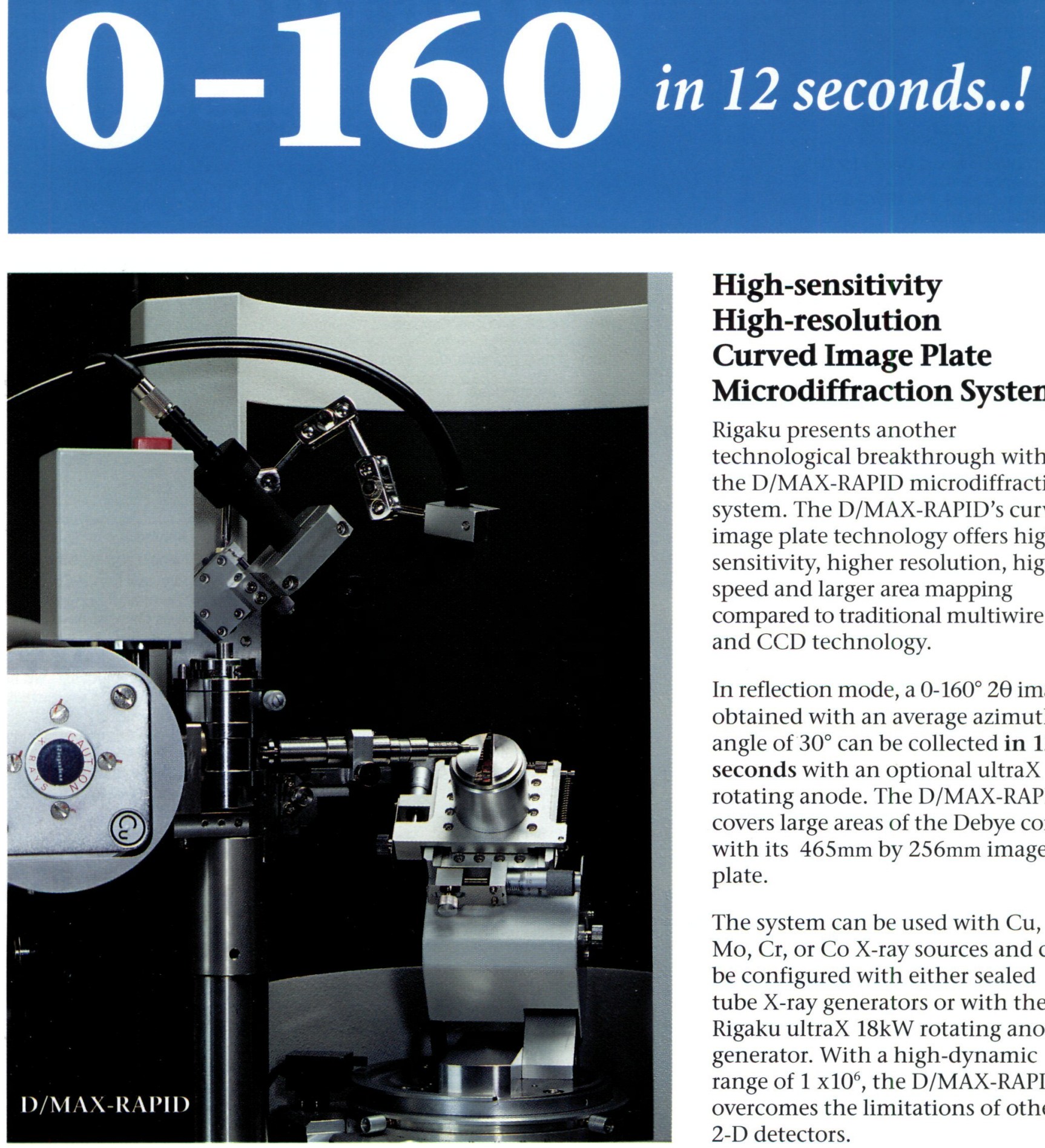

High-sensitivity High-resolution Curved Image Plate Microdiffraction System

Rigaku presents another technological breakthrough with the D/MAX-RAPID microdiffraction system. The D/MAX-RAPID's curvec image plate technology offers highe: sensitivity, higher resolution, highes speed and larger area mapping compared to traditional multiwire and CCD technology.

In reflection mode, a $0-160^{\circ} 2 \theta$ image obtained with an average azimuthal angle of $30^{\circ}$ can be collected in 12 seconds with an optional ultraX rotating anode. The D/MAX-RAPID covers large areas of the Debye cones with its $465 \mathrm{~mm}$ by $256 \mathrm{~mm}$ image plate.

The system can be used with $\mathrm{Cu}$, Mo, Cr, or Co X-ray sources and can be configured with either sealed tube X-ray generators or with the Rigaku ultraX 18kW rotating anode generator. With a high-dynamic range of $1 \times 10^{6}$, the D/MAX-RAPID overcomes the limitations of other 2-D detectors.

Advanced features of the D/MAX-RAPID include:

- Fast phase identification

- Polymer and fiber diffraction

- Texture and orientation

- Percent crystallinity

- Crystallite size

- Microdiffraction

- Selected-area diffraction

(Diffraction-function mapping)
- Stress

- Forensics

- Inclusions

- High-pressure diamond anvil studies

- Single crystal diffraction (with optional single crystal software/hardware package)

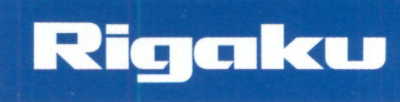

9009 New Trails Drive

The Woodlands, TX 77381

Tel: (281) 367-2685

Fax: (281) 364-3628

http://www.rigaku.com/pd 


\section{EDITORIAL}

\section{TECHNICAL ARTICLES}

Alan D. Mighell

Shigeo Hayashi, Hideo

Toraya

F. Weitzer, L. Perring, T.

Shibayanagi, M. Naka, and

J. C. Schuster and E. J. MacLean

Charles Buckner, Peter

Varlashkin

I. Erkin Gönenli,

A. Cüneyt Tas
Victor E. Buhrke

K. D. Rogers, M. W. Sperrin,

Should incomplete papers be published?

81

Lattice metric singularities and their impact on the indexing of powder

82 patterns

Quantitative phase analysis of natural products using whole-powder-pattern decomposition

Determination of the crystal structure of CuSnTi by full profile Rietveld analysis

A synchrotron study of bladder urolith architecture

Cover to provide an inert atmosphere for XRD sample changers

Chemical preparation of aluminum borate whiskers

\section{NEW DIFFRACTION DATA}

Ruggero Caminiti, Giancarlo

Powder X-ray data for melatonin $\mathrm{C}_{13} \mathrm{H}_{16} \mathrm{~N}_{2} \mathrm{O}_{2}$

108

Ortaggi, Raffaele Antonio

Mazzei, Paolo Ballirano, and

Rita Rizzi

Ruggero Caminiti, Giancarlo

Ortaggi, Raffaele Antonio

Mazzei, Paolo Ballirano, and

Rita Rizzi

W. Paszkowicz

N. Audebrand, M. Ellner, and

E. J. Mittemeijer

Iris Meusel, Wilhelm

Barthlott, Hartmut Kutzke, and Bruno Barbier

N. Subramanian, N. V.

Chandra Shekar, P. Ch. Sahu, Mohammad Yousuf, and K.

Govinda Rajan

Carlos O. Paiva-Santos, Talita Mazon, Maria A. Zaghete,

André L. Campos, J. A.

Varela, and Cesar R. Foschini

V. Kahlenberg, $M$.

Wendschuh-Josties, R. X.

Fischer, H. Bauer, J. Holz, G.

Schimmel, and A. Tapper
Powder X-ray data for adenosine $\mathrm{C}_{10} \mathrm{H}_{13} \mathrm{~N}_{5} \mathrm{O}_{4}$

Powder diffraction data of semimagnetic semiconductors $\mathrm{Hg}_{0.80} \mathrm{Mn}_{0.20} \mathrm{~S}$,

$\mathrm{Hg}_{0.89} \mathrm{Fe}_{0.11} \mathrm{~S}$ and $\mathrm{Hg}_{0.98} \mathrm{Co}_{0.02} \mathrm{~S}$

Powder diffraction data for the germanides $\mathrm{CoGe}$ and $\mathrm{Co}_{5} \mathrm{Ge}_{7}$

120

Crystallographic studies of plant waxes

Powder X-ray diffraction data of BaFI

Crystal structure of $\mathrm{BaBi}_{2} \mathrm{Ta}_{2} \mathrm{O}_{9}$

$\mathrm{X}$-ray powder diffraction data for $\delta-\mathrm{Na}_{2} \mathrm{Si}_{2} \mathrm{O}_{5}$

\section{INTERNATIONAL REPORTS}

Regional Reports

Poster Session

Calendar of Meetings

Short Courses and Workshops

Notes for Authors 


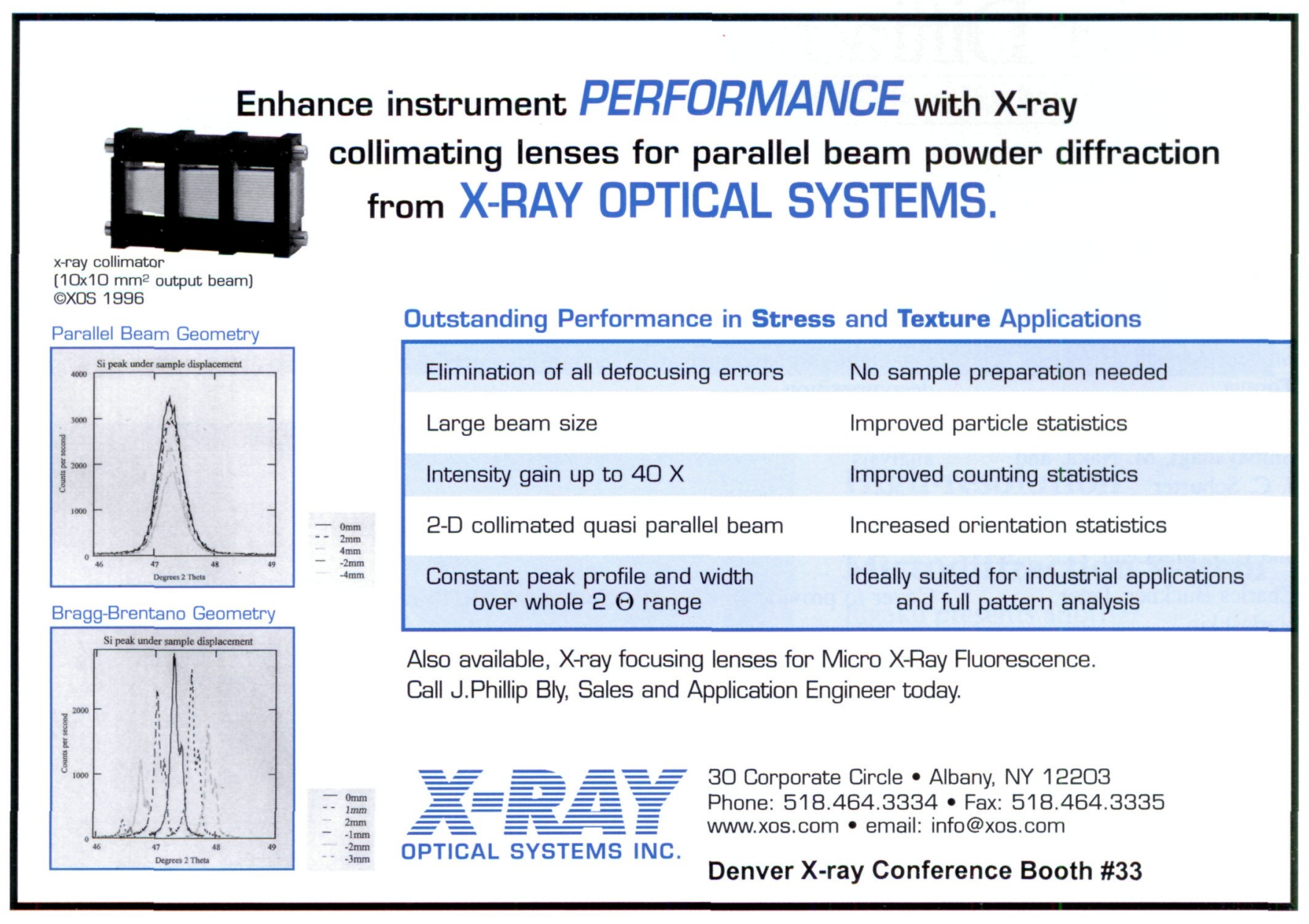

\section{(}

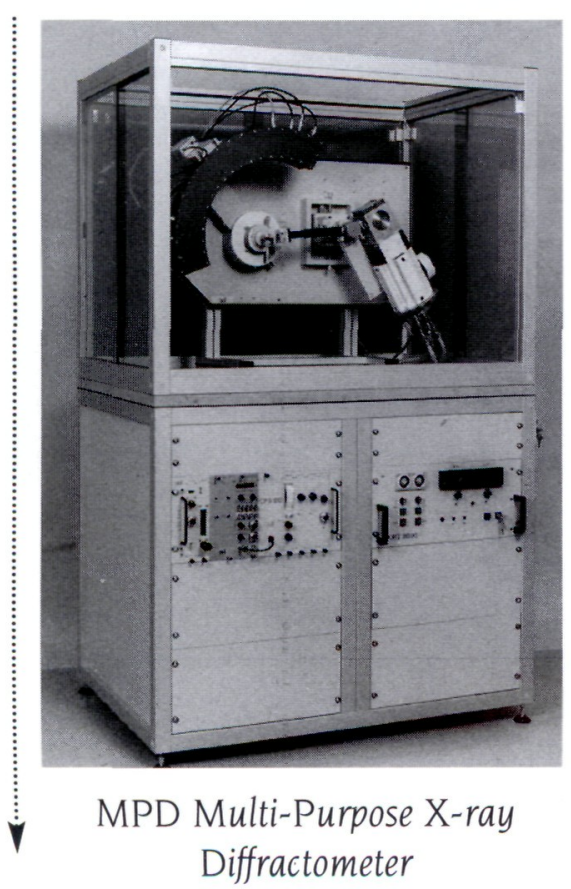

Versatile diffractometers designed to take advantage of the rapid, real time data collection our patented CPS X-ray detectors offer.

${ }^{*}$ No scanning feature - acquire up to $120^{\circ} 2 \theta$ simultaneously -Unique capillary devices for analysis of air sensitive materials -Identify materials even if only micro amounts are available -Parallel beam with germanium or multilayer mirror optics for information on our complete product line please contact us inel - Z.A - CD 405 - 45410 ARTENAY (FRANCE) Tel. (33) 0238804545 Fax. (33) 0238800814 E.MAIL: inel@valcofim.fr-INTERNET:http://www.valcofim.fr/inel

inel Inc. P.O. Box 147, STRATHAM, NH 03885 (USA) TEL. (603) 778-9161 FAX. (603) 778-9171 E-MAIL: inelinc@aol.com

Denver X-ray Conference Booth \#27 


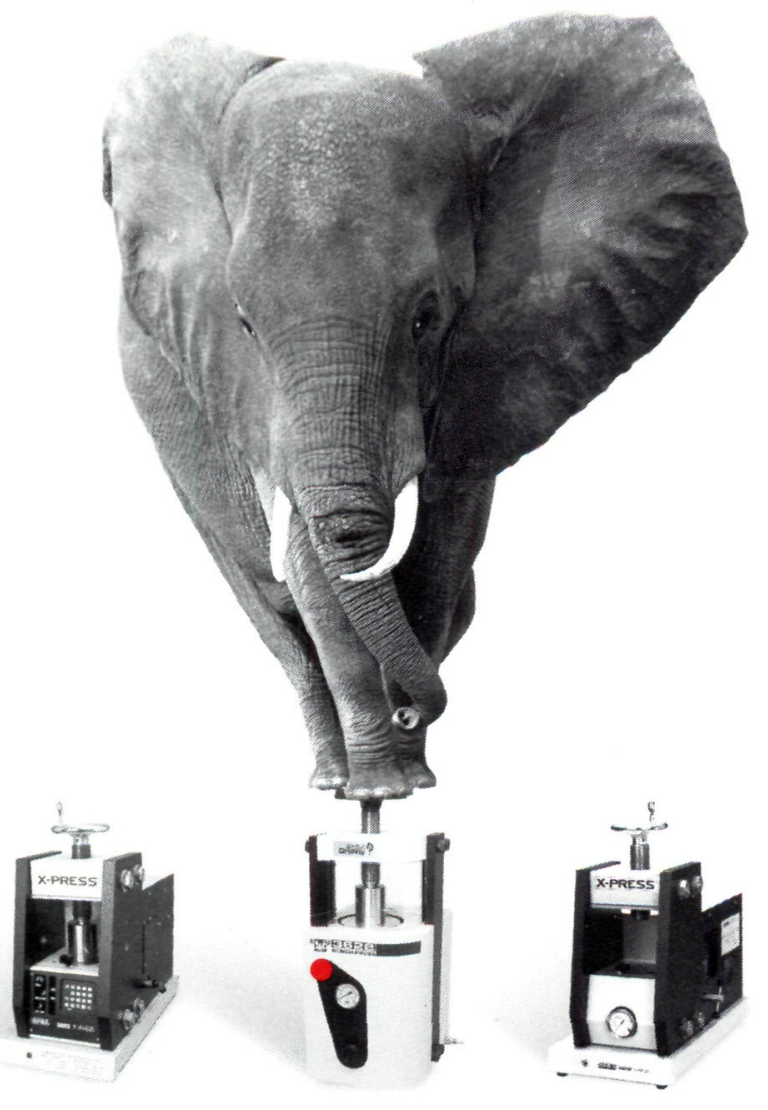

\section{Performs Great Under Pressure}

SPEX CertiPrep introduces a unique manual press which performs with the greatest of ease! Try one out today and start reducing your sample pelletizing costs to mere peanuts a day!

The Air-actuated Bench-Press ${ }^{\mathrm{TM}}$ eliminates the tedious task of hand pumping, necessary with other manual presses. Just push the button and the Bench-Press will generate up to 25 Tons of pressure for sample pelletizing.

SPEX CertiPrep also offers the X-Press Series of 35 ton, automated laboratory presses, the 3630 and the 3624B.

A variety of pellet dies, reinforcing caps (SPEC-Caps), and Prep-Aid ${ }^{\mathrm{TM}}$ (sample binder) are also available to meet all of your sample pelletizing needs.

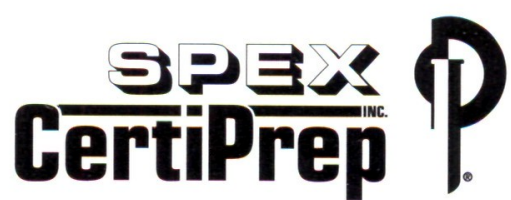

203 Norcross Avenue, Metuchen, NJ 08840

Website: $\quad$ www.spexcsp.com Phone: 732-549-7144 Fax: $\quad$ 732-603-9647

1-800-LAB-SPEX・ sampleprep@spexcsp.com (e-mail)

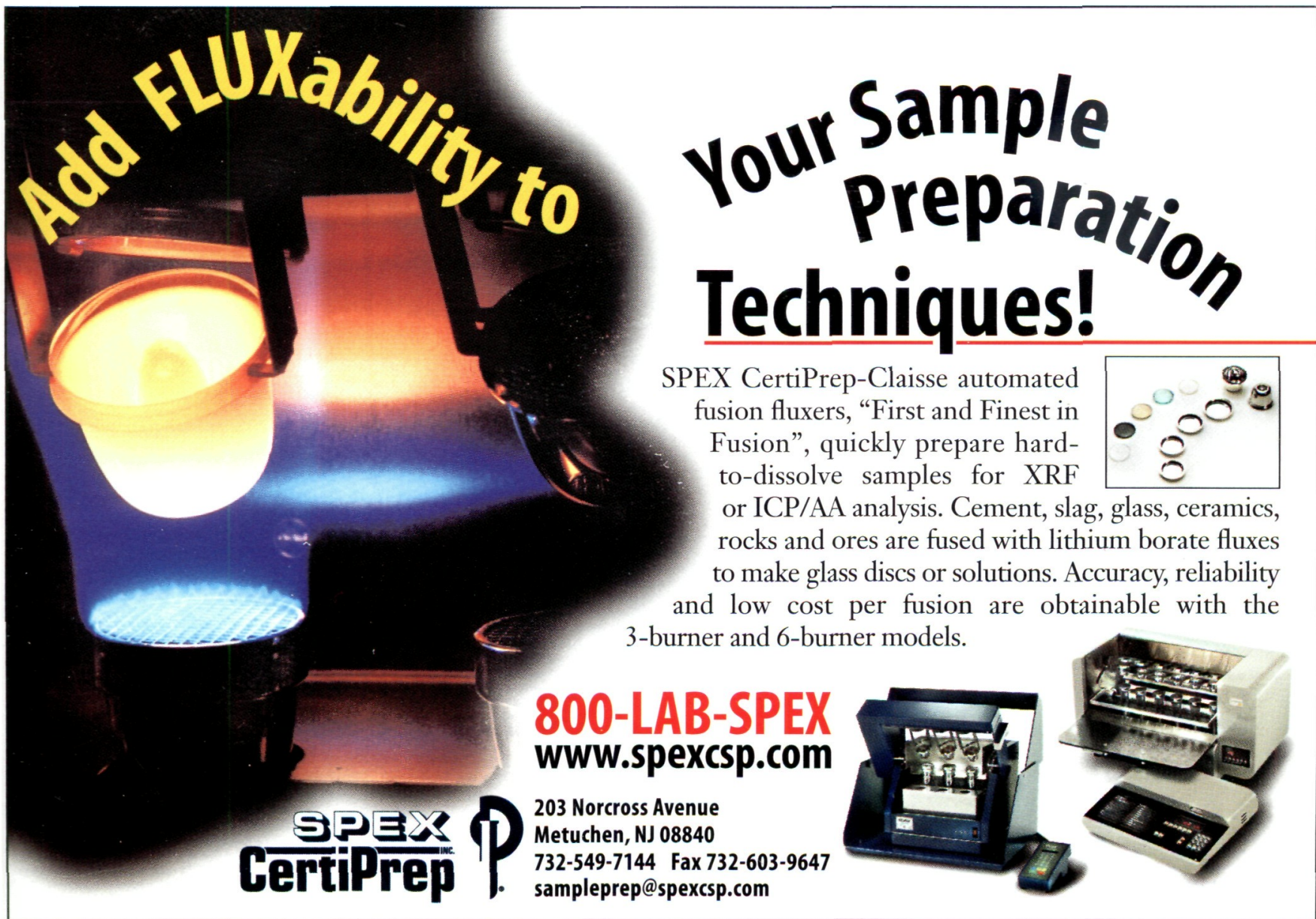




\section{8
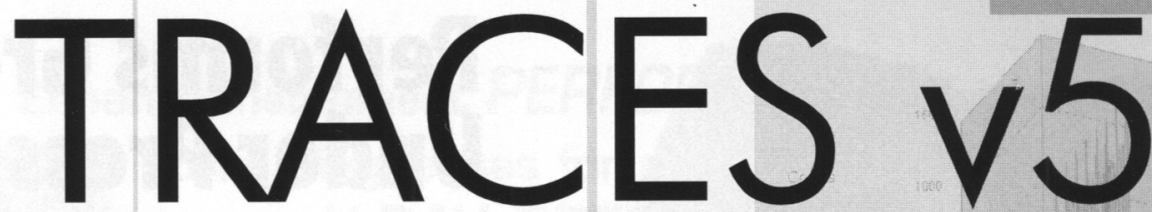 \\ One of the world's most popular Powder Diffraction Scan Processing packages has just got better!}

With integrated Peak Fitting, Quantitation, Search/Match,

Database access \& creation, Indexing, Unit Cell refinement available as standard or option, as well as being one of the most user - friendly packages around,

Traces $v 5$ is great value for money.

Visit our Website \& download a Demo copy for yourself

Diffraction Technology Mh

Australia: Rod Clapp

Unit 3/38 Essington St, Mitchell A.C.T 2911

PO Box 444 Mitchell A.C.T, 2911

Ph. (02) 62428233 , Fax. (02) 62428266

difftech@difftech.com.au www.difftech.com.au

United States: Jerry Krause

Analytical X-ray Instrument Sales

Phone/Fax: 3032771569

Internet: jkxray@aol.com
United Kingdom: Arthur Bagley

Hiltonbrooks Ltd.

Phone: 01477534140

Fax: 01477535041

Internet: arthur@xrays.u-net.com

Get specialty beryllium prototypes with production processing in mind.

\section{Driven to perform?}

\section{Come to us. We'll put the metal to the metal.}

When your production schedule is short, you want to get it done right the first time. You can eliminate a major uncertainty when you entrust your custom beryllium fabrication, joining and coating to us. We'll help you shine.

Here's what we can do for you:

- Depend on us as the only fully integrated source for beryllium sheet and foil products. All critical operations are performed in-house for seamless excellence.

- We're your partner in joining and coating metals. When your project involves joining a metal to a metal, you can count on us.

- Come to us for all your UHV beryllium product needs: $\mathrm{x}$-ray windows, chambers, beam pipes and more.

- Rely on our expert engineering. We like challenges. Taking your design concept into reality would be our pleasure.

Count on us for your tough jobs. Keep in mind that we're the only fully integrated source for beryllium products for the analytical, medical, and scientific industries. Challenge us with your "cutting edge" requirements. We look forward to hearing from you.

TEL: 510-623-1500 - FAX: 510-623-7600

E-Mail:Electrofusion@BrushWellman.com

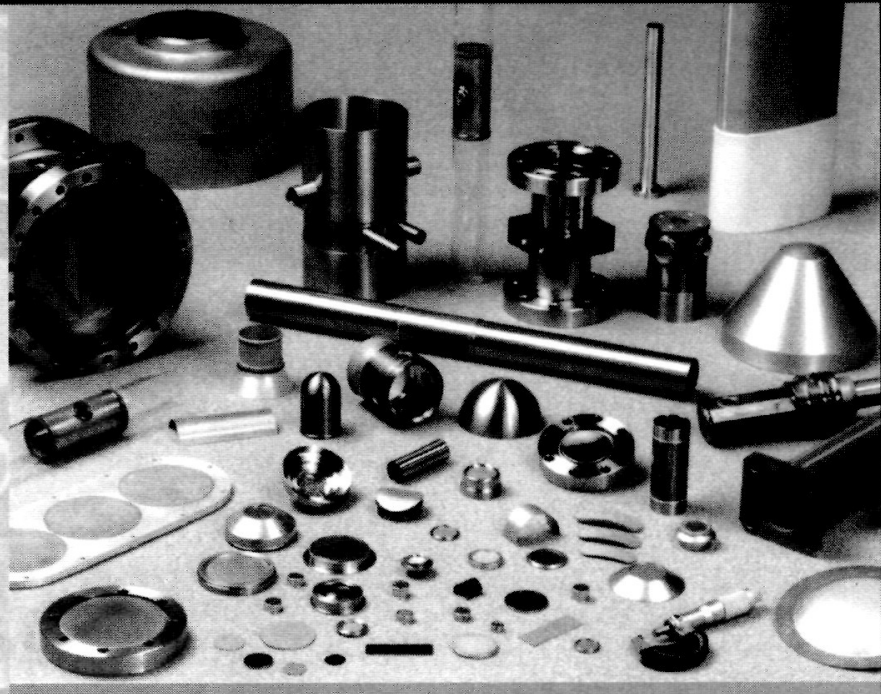

BRUSHWLLLIMAN ELECTROFUSIONPRODUCTS We're the beryllium window folks. 


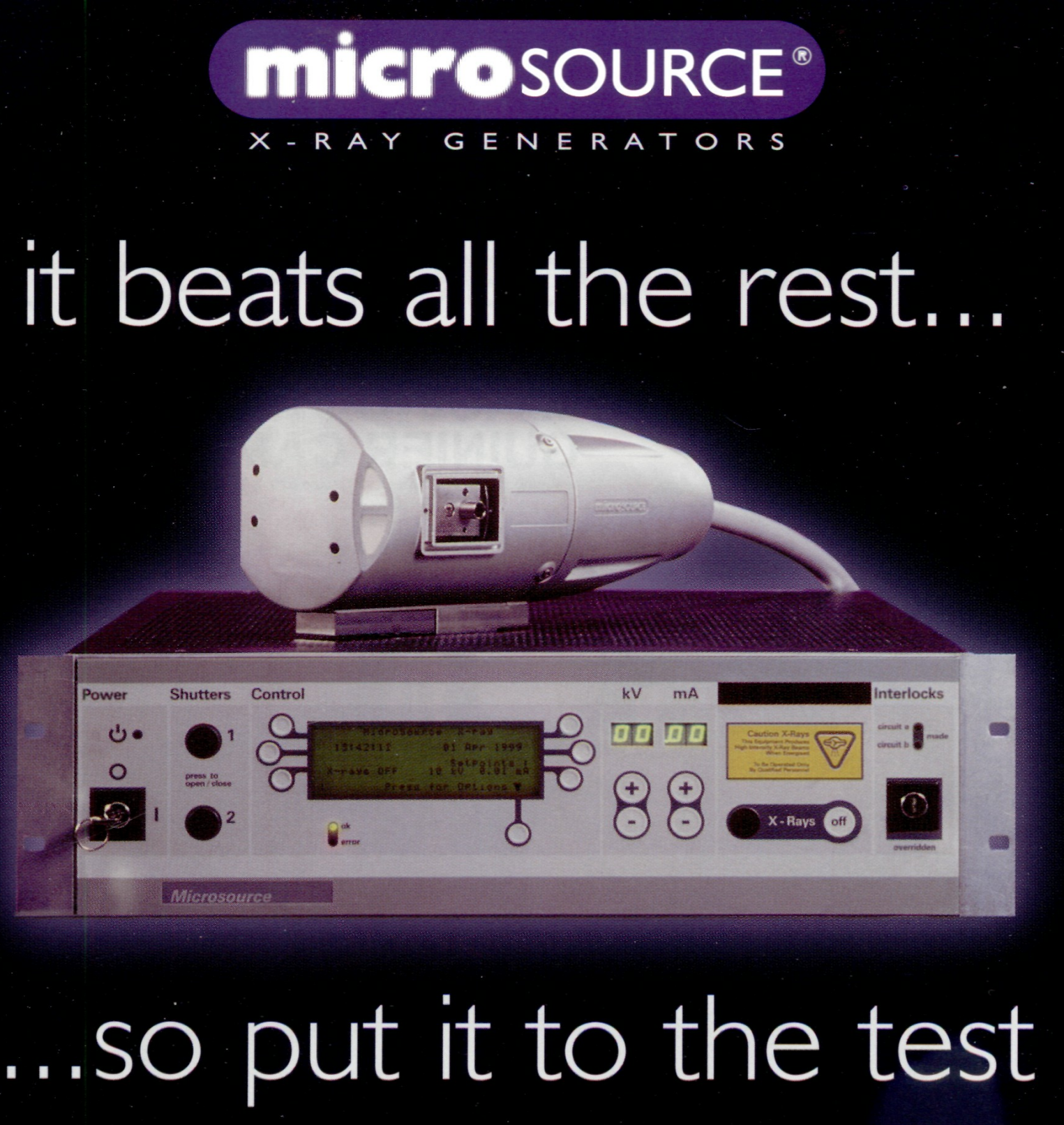

Contact us for examples of the excellent data we have collected and to learn how we can help you to maximise your laboratory's potential.

Demonstrations available on request

The Microsource ${ }^{\circledR}$ X-ray Generator gives you a complete system for less than $\$ \mathbf{7 5 , 0 0 0 *}$ complete system

including tube mount, tube shield, $\mathbf{X}$-ray optic (micromirror $\left.{ }^{\circledR}\right)$ with built in alignment for $\mathbf{X}$-ray focusing

compatibility

proven interface to

different systems performance

proven $10^{10}$ photons $\mathrm{s}^{-1} \mathrm{~mm}^{-2}$ together with low divergence for a variety of applications

\section{future proof}

modular design,

rapid servicing.

upgradability

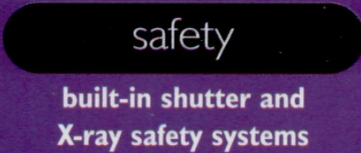

$X$-ray safety systems economy

low power consumption, low cost of ownership, small footprint

For enquiries within USA, Canada \& Mexico contact:

Dr D Keith Bowen, Bede Scientific Incorporated 14 Inverness Drive East, Suite G-104, Englewood, CO 801 12, USA Tel: 303.790.8647•Fax: 303.790.8648-Email: sales@bede.com Website: www.bede.com

For the rest of the world contact:

Dr Graham Fraser, Bede Scientific Instruments Ltd.

Bowburn South Industrial Estate, Bowburn, Durham, DH6 5AD, UK

Tel: $+44(0) 1913772476$ - Fax: +44 (0) 1913779952

Email: microsource@bede.co.uk -Website: www.bede.co.uk

*Price F.O.B. Durham, UK

microsOURCE ${ }^{\circledR}$ is a Division of Bede Scientific Instruments Ltd 

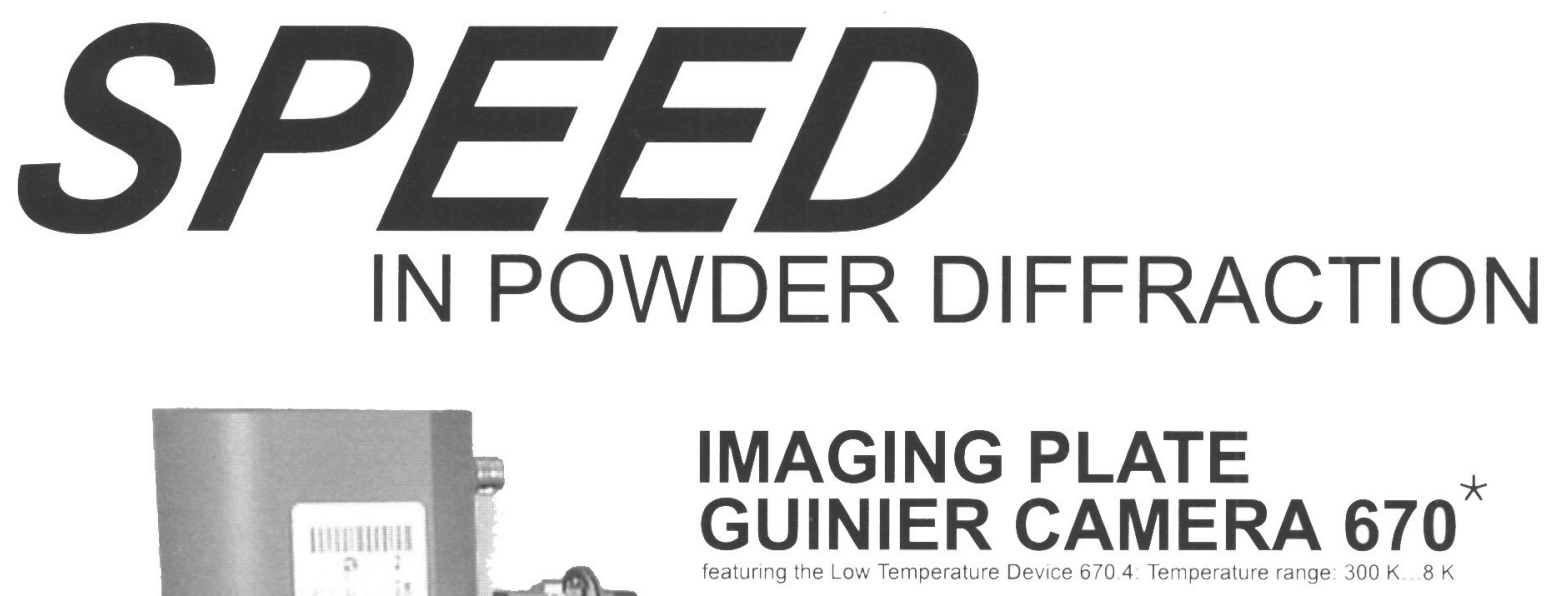

* FAST, FLEXIBLE \& FREE OF K $\alpha_{2}$

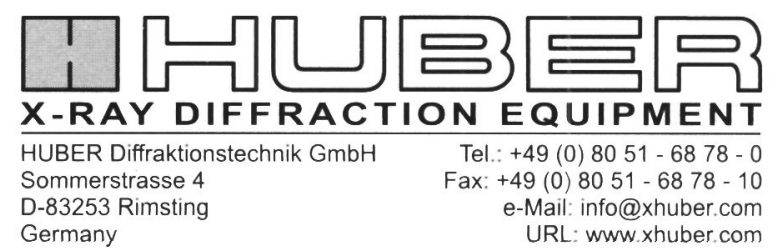




\section{Explore the Mew}

\section{Kratos/SHIMAdZU X-RAY Laboratory powerful technologies for Elemental analysis Solids, LIavids, Powders \& Wafers}

\section{EDXRF}

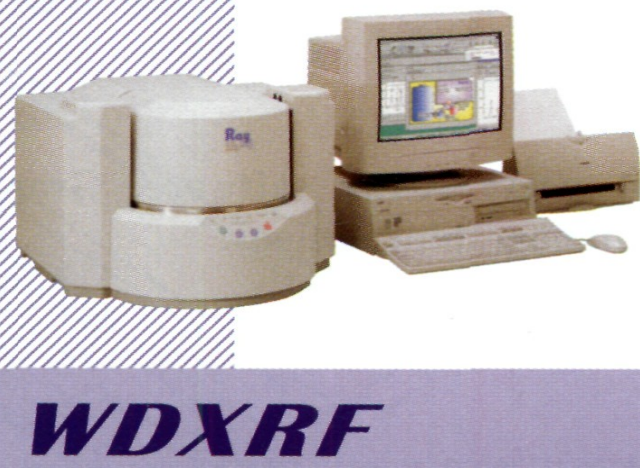

$E D X-800$

ENERGY DISPERSIVE X-RAY FLUORESCENCE SPECTROMETER

Simple, Powerful Performance.. Simultaneous Measurement of Carbon to Uranium With A Touch of a Button 300MM Wafer Handling Facilities Analysis in Helium, Vacuum or Air

Fully Automated Measurements Local Area Analysis with Scanning Standardless Fundamental Parameters Large Chamber with Automated Open/Close

The Only Imaging Wavelength Dispersive Instrument in the World..

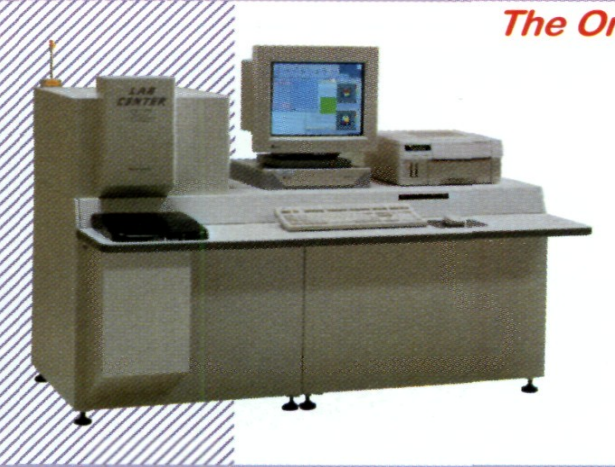

XRF-1700

SEQUENTIAL X-RAY FLUORESCENCE SPECTROMETER

$X \boldsymbol{R D}$

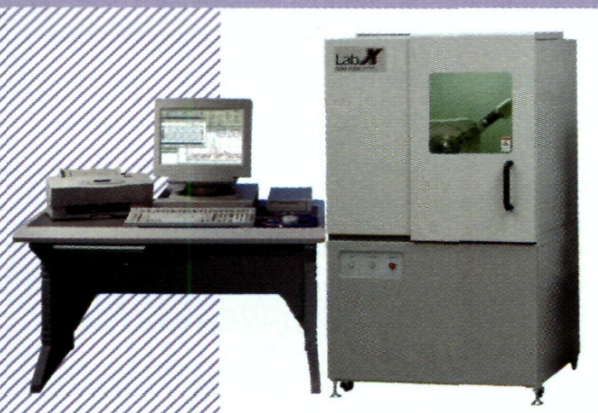

Ultra High Performance, Speed and Versatility

for Qualitative \& Quantitative Analysis

Rapid Qualitative Analysis of Elements Be to $U$

$1 \mathrm{~mm}$ Local Area Analysis with Mapping $30 \mathrm{~mm}$ Wide Area Analysis Reliable Determination of $C, H \& O$ Quantitative Data from RhKa Scattering \& FP Methods Ultra High Resolution, Sensitivity \& Accuracy Simple, Powerful Multi-Tasking Operation

XRD -6000

PRECISION ENGINEERED X-RAY DIFFRACTION SYSTEM Fast \& Accurate Identification \& Quantification Of

Crystalline Compounds and Structures Precision Engineered, Compact X-Ray System High Stability X-Ray Generator

High Precision/High Speed Goniometer Multi-Tasking Support/Parallel Processing Consistent, Reliable Operation Low Cost of Ownership Ask about our new applications booklet on solid state pharmaceutical products

Q a. of and oday for more information: PHoNe: 01 4026-6700 FAX: (914)426-6192

E-Mall: info@kratos.com MUIERNET: http://www.kratos.com

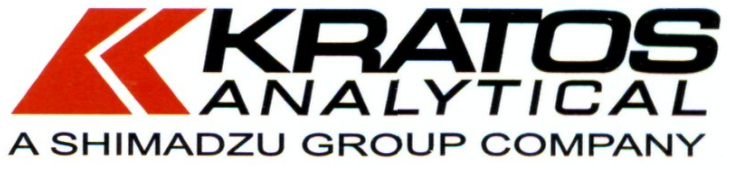




\section{Your Software For X-Ray Analysis}

Now optimized for the new, enhanced PDF database with more than 42,000 additional calculated patterns

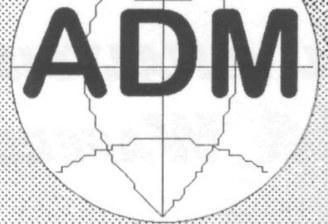

PADS

New Edition

Sof ware package for data acquisition and analysis:

Bifrectameter control, plot modules, peak search and calibration, qualitative and quantitative ply ke antivsk, profile fitting and pattern simulation, lattice parameter refinement, crystullite size and micro stress.

Ready to plug to your PHILIIPS and SHCMLXS diffractometer hardware.

Stand alone package for qualitative and quantitative phase analysis.

Extremely fast search algorithms for ICDD-PDF d flabase and user created databases. Very exact quantitative analysis using the WHOI. PATIERN method.

X'TEND

Extension package for most third party X-ray software. Graphicanalytical, profile-analytical and crystallographic options.

\section{a. Wassermann}

P. O. BOX 2631, D-87416 Kempten, Gernany, Tel. (49)0831-79515, FAX (49)0831-79930, E-mail. RMSKemptena aol.com

\section{Expand your x-ray}

diffraction capabilities not your overhead.

Whether you just need services or your XRD lab is on "overload," IC Laboratories provides every testing service and advanced capability you need in qualitative or quantitative $\mathrm{x}$-ray diffraction analysis - from austenite to zeolites, from air filters to thin films. You are assured of rapid turn-around of results - as little as 48 hours - because IC Labs is one of the most highly automated commercial labs in the U.S., with knowledgeable personnel ready to address all your applications. For a copy of our technical prospectus, contact IC Laboratories.

\section{IC Laboratories}

Post Office Box 721 Amawalk, New York 10501 (914) $962-2477$ www.ICLABS.com 
Osmic Optics...

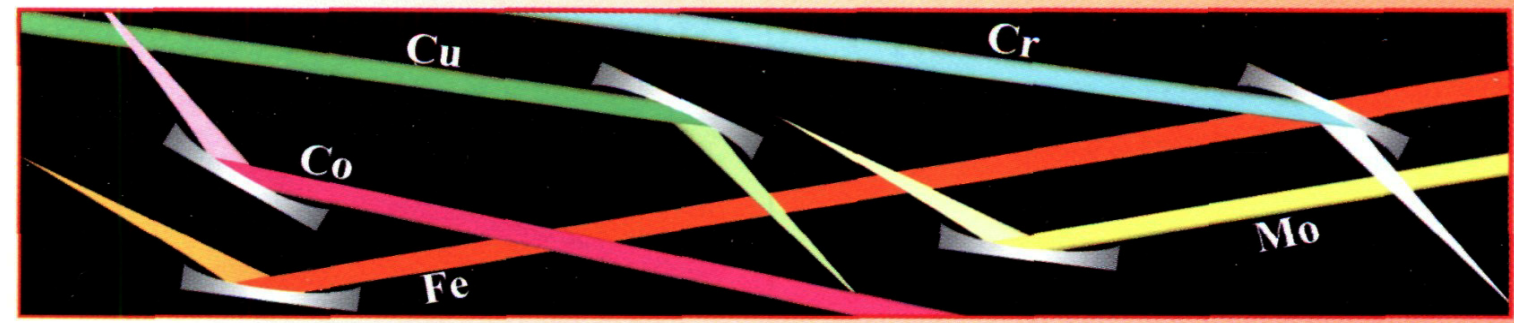

Max-Flux ${ }^{\mathrm{TM}}$

Powder
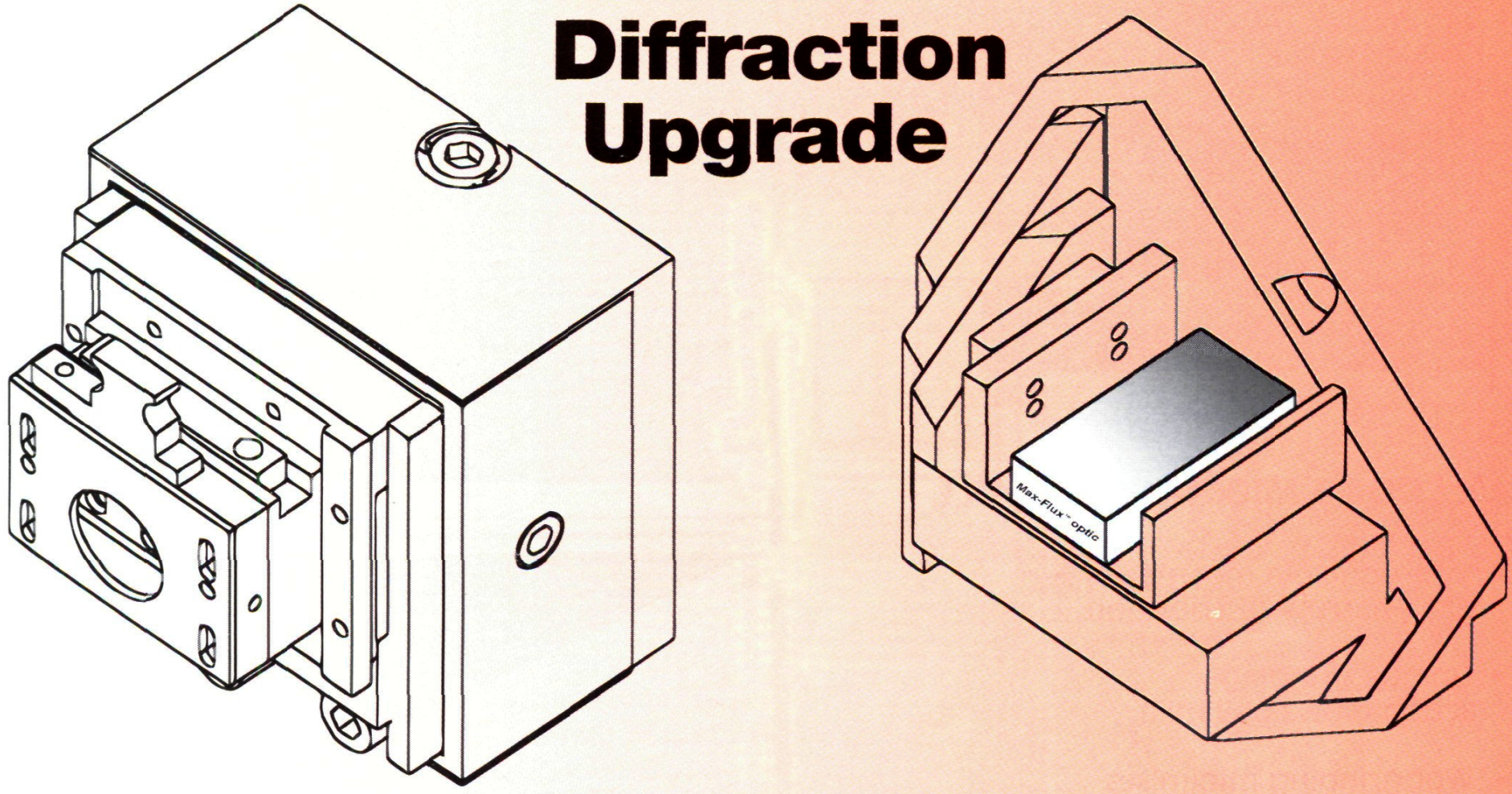

\section{Benefits}

- Reduction of sample displacement errors

- Enables testing of irregularly shaped samples

- Increased resolution

- Higher flux

- Lower background

\section{Applications}

- Thin Film Analysis

- High Resolution

- Phase Analysis

- Stress / Strain Measurements

- Texture Analysis

- Point-Defect Analysis

- And more...

Denver X-ray Conference Booth \#26

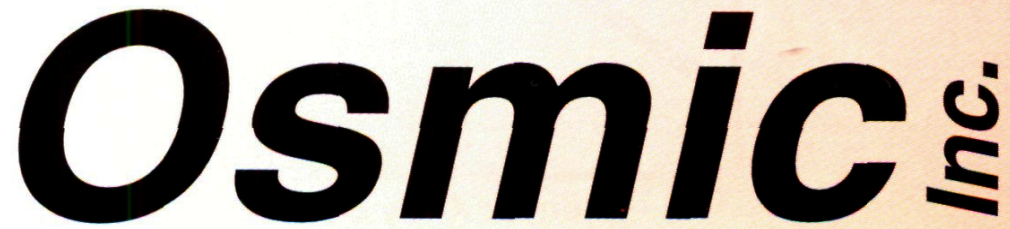

1788 Northwood Drive

Troy, Michigan 48084-5532, USA tel: 248.362.1290 fax: 248.362 .4043 


\section{Rapid particle size reduction}

for XRD, XRF and IR

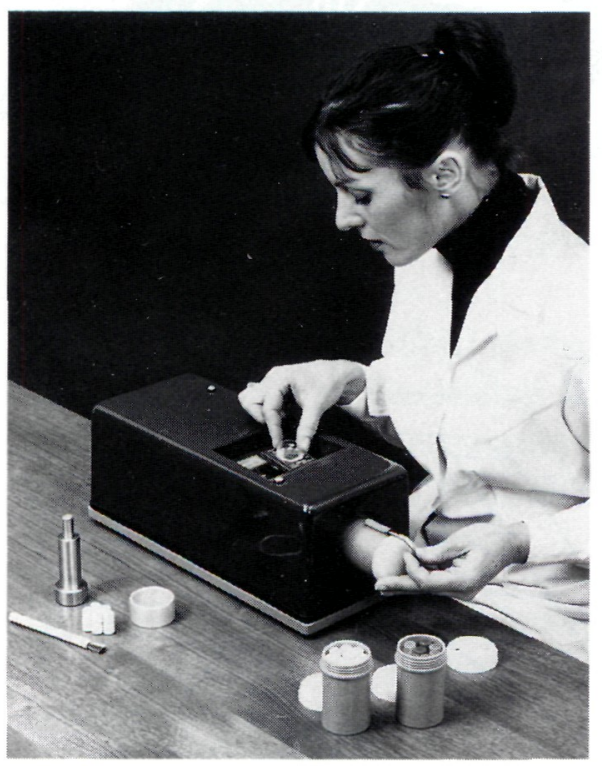

\section{MCCRONE MICRONISING MILL}

- Reproducible mean particle size - narrow distribution

- Unique grinding action (not a ball mill)

- Wet grinding minimises damage to sample crystallinity

- Choice of grinding elements (agate or corundum)

Mccrone Scientific Ltd.

Mccrone House, 155A Leighton Rd. London NW5 2RD. U.K.

tel: 02072677199 fax: 02072673383

e-mail: saramark@mccronescientific.sagehost.co.uk

\section{USA Distributor:}

Mccrone Accessories \& Components 850 Pasquinelli Drive

Westmont, Illinois 60559-5531

phone: 6308877100 fax: 6308877764

e-mail: MAC@mccrone.com
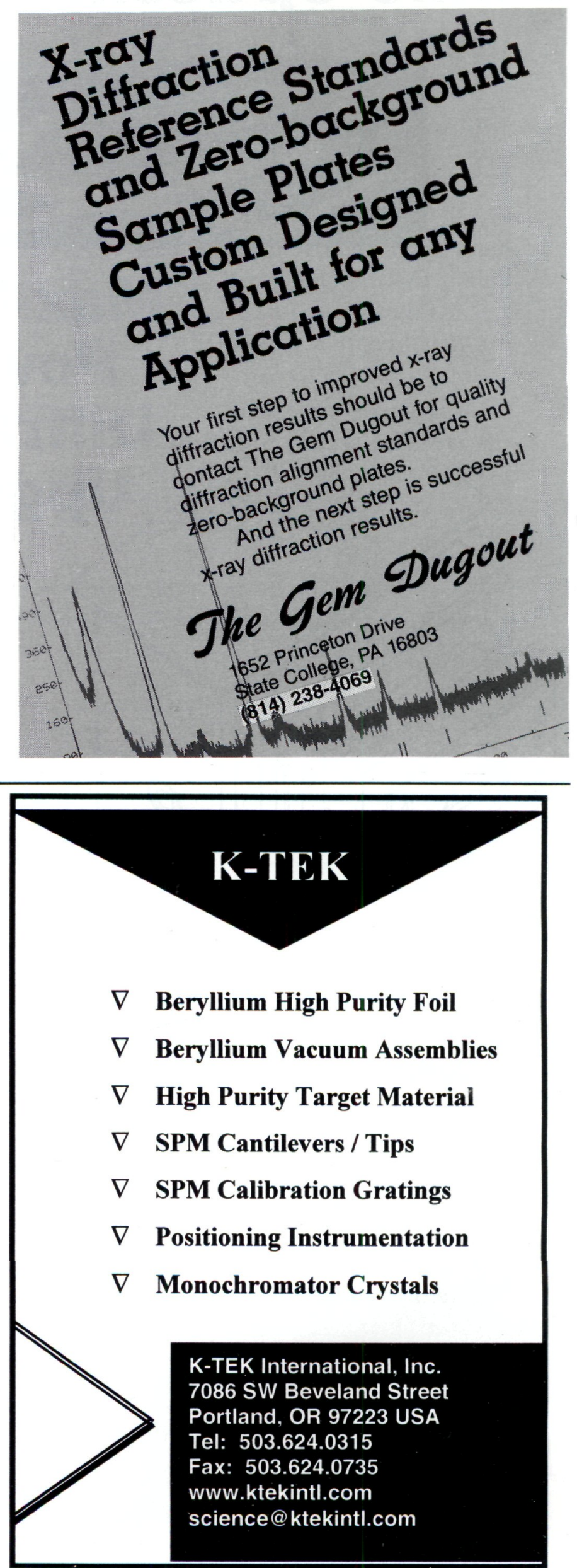

Denver X-ray Conference Booth \#40 


\section{Publishing Agreement}

1. It is our custom to request authors to vest the worldwide copyright of their papers with the JCPDS-International Centre for Diffraction Data for the full term of copyright and we would be grateful if you would confirm your acceptance of these terms by signing and returning the agreement below. We will not withhold permission for any reasonable request from you to publish any part of this paper in connection with any other work by you, provided the usual acknowledgements are given regarding copyright notice and reference to the original publication.

2. If it is appropriate, the author's employer may sign this agreement, and in any event the employer may reserve the right to use the paper internally or for promotional purposes only, by so indicating on this agreement. It is understood that proprietary rights other than copyright (including patent rights) are reserved.

3. If the author is a U. S. Government employee and this work was done in that capacity the assignment applies only to the extent allowable by U. S. law. If at least one co-author is not a government employee, said author should sign the agreement.

4. If the author is an employee of the British Government then HMSO will grant a non-exclusive license to publish this paper in the Journal in any form or media provided British crown copyright and user rights (including patent rights) are reserved.

5. The author warrants that the manuscript is the author's original work, and has not been published before. (If excerpts from copyrighted works are included, the author will obtain written permission from the copyright owners and show credit to the sources in the manuscript.) The author also warrants that the article contains no libelous or unlawful statements, and does not infringe on the rights of others.

6. If the work was prepared jointly the author agrees to inform co-authors of the terms of the agreement, and to sign on their behalf.

With the qualifications listed above I assign to JCPDS-International Centre for Diffraction Data, the copyright of my paper entitled

for publication in Powder Diffraction.

If the paper is rejected, this assignment is null and void. 